\title{
Experimental Study on Roller Compacted Concrete Pavement
}

\author{
P.Sankara Narayanan ${ }^{1}$, M.Palanikumar ${ }^{2}$ \\ \{sankarpraba92@gmail.com ${ }^{1}$, mpk.civil@psgtech.ac.in² \\ ${ }^{1}$ Former Post Graduate student, ${ }^{2}$ Associate Professor, Department of Civil Engineering, PSG College of \\ Technology, Coimbatore, India
}

\begin{abstract}
In this project a study of Roller Compacted Concrete (RCC) has been done restricting the scope to laboratory tests. Since concrete also consists of solids, water and air like soil, the maximum dry density and the optimum moisture content are determined for the RCC in the laboratory. Based on this, casting of specimens is done by compacting with $4.89 \mathrm{~kg}$ rammer producing heavy compactive energy at optimum moisture content. Test results indicate that this concrete can be used for paving applications, because the flexural strength has been found to be more than 4.5 MPa. Hence, a comparison of RCC pavement with conventional pavement is needed to explore the advantages and to strongly recommend the same for pavements. Conventional concrete shows more flexural strength than RCC, but the difference in required thickness of pavement designed as per IRC 58:2011 is very small. Taking into consideration the men, materials and equipment usage, RCC pavement is found to be cheaper. If future study on the chemical behaviour of RCC is carried out, more solutions can be found for mass concreting problem.
\end{abstract}

Keywords; Roller Compacted Concrete, mix proportion, Heavy compaction test, Optimum Moisture Content, flexural strength

\section{Introduction}

Roller compacted concrete (RCC) is made up of zero slump concrete compacted using vibratory rollers, layer by layer to obtain the desired depth.

$\mathrm{RCC}$ is compacted using steel drum rollers and rubber tyred vibratory rollers which are usually used for compacting the various components of flexible pavement. So the concrete should be dry enough to resist the weight of the roller and wet enough to ensure complete paste distribution filling the voids. The concrete becomes very dense and stiff in a very economical and fast method of construction. The road can be put to use in 24 hours of laying.

S.KrishnaRao [1] conducted a study onevaluation of properties of Roller Compacted Concrete Pavement (RCCP). The test results indicate that RCC is a stiff, zero-slump concrete mix and has the same ingredients as that of conventional concrete. It is mixed, placed, and compacted using the same type of equipment that is used for asphalt pavement construction and can be proportioned using soil compaction method. Flexural and compressive strengths increase with increase in cement content.

Mahdi Alikhani and FereydounmoghadasNejad[2] conducted a study on properties and performance of roller compacted concrete pavement and its economic evaluation and concluded that roller compacted concrete pavement could be used in areas with steep slopes 
and hot weather with a heavy and slow loading where asphalt pavement has a problem and is not amenable.

S. Pavan and S. Krishna Rao [3] in their study on the influence of fly ash on RCC concluded that the replacement of cement with fly ash reduces the split tensile strength, flexural strength and compressive strength of the concrete.

\section{Experimental Program}

A dense concrete has high strength and stiffness. RCC requires a well graded mix as well as appropriate compactive energy. In this study, four kinds of aggregates namely course aggregates, 10-mm chips, sand and quarry dust are selected to have a well graded mix. These four materials do not produce a dense concrete individually but when they are mixed in a particular proportion, a dense mix is produced. After finding this proportion, heavy compaction test is conducted on the mix to determine Optimum Moisture Content (OMC). This moisture content is added to the RCC to produce a concrete with maximum density. The term 'water-cement ratio' does not play a role here.

\subsection{Mix Proportioning for RCC}

ACI 211.3R-02 [4] recommends a cement content of $14 \%$ by weight of total aggregates for obtaining flexural strength of 4.5 MPa. Based on the sieve analysis results obtained for various aggregates, a perfect mix of them is to be obtained using Rothfuch graphical method such that the mix obtained from them satisfies thegradation requirements specified byACI 211.3R-02given in Table 1. Hence, if the percentage finer of the mix obtained is within the range specified, then that proportion can be used for the mix.

Table1 Combined gradation required
\begin{tabular}{|c|c|}
\hline $\begin{array}{c}\text { Sieve size, } \\
\text { mm }\end{array}$ & \% Finer \\
\hline 25 & 100 \\
\hline 20 & 82 to 100 \\
\hline 12.5 & 72 to 93 \\
\hline 10 & 66 to 85 \\
\hline 4.75 & 51 to 69 \\
\hline 2.36 & 38 to 56 \\
\hline 1.18 & 28 to 46 \\
\hline 0.600 & 18 to 36 \\
\hline 0.300 & 11 to 27 \\
\hline 0.150 & 6 to 18 \\
\hline 0.075 & 2 to 8 \\
\hline
\end{tabular}

The results of sieve analysis conducted on course aggregate, 10-mm chips, sand and quarry dust are given in Table 2, 3, 4 and 5 respectively. Individually none of these materials satisfies the gradation requirement given in Table 1. 
Table 2 Results of sieve analysis on course aggregate

\begin{tabular}{|c|c|}
\hline Sieve size, $\mathbf{~ m m}$ & \% Finer \\
\hline 25 & 100 \\
\hline 20 & 69.98 \\
\hline 16 & 4.64 \\
\hline 12.5 & 0.32 \\
\hline 10 & 0.12 \\
\hline 6.36 & 0.06 \\
\hline 4.75 & 0.06 \\
\hline
\end{tabular}

Table 3 Results of sieve analysis on 10-mm chips

\begin{tabular}{|c|c|}
\hline $\begin{array}{c}\text { Sieve size, } \\
\text { mm }\end{array}$ & $\begin{array}{c}\text { \% } \\
\text { Finer }\end{array}$ \\
\hline 12.5 & 99.54 \\
\hline 10 & 96.08 \\
\hline 6.36 & 36.15 \\
\hline 4.75 & 10.05 \\
\hline 2.36 & 1.07 \\
\hline 1.18 & 0.77 \\
\hline 0.6 & 0.63 \\
\hline 0.3 & 0.49 \\
\hline 0.15 & 0.32 \\
\hline 0.075 & 0.1 \\
\hline
\end{tabular}

Table4 Results of sieve analysis on sand

\begin{tabular}{|c|c|}
\hline $\begin{array}{c}\text { Sieve size, } \\
\text { mm }\end{array}$ & $\begin{array}{c}\text { \% } \\
\text { Finer }\end{array}$ \\
\hline 4.75 & 97.8 \\
\hline 2.36 & 94.4 \\
\hline 1.18 & 82.8 \\
\hline 0.6 & 49.2 \\
\hline 0.3 & 24.8 \\
\hline 0.15 & 2.2 \\
\hline 0.075 & 1.2 \\
\hline
\end{tabular}

Table 5 Results of sieve analysis on Quarry Dust

\begin{tabular}{|c|c|}
\hline Sieve size, $\mathbf{~ m m}$ & \% Finer \\
\hline 4.75 & 97.6 \\
\hline 2.36 & 93.2 \\
\hline 1.18 & 83.6 \\
\hline 0.6 & 68.8 \\
\hline 0.3 & 52 \\
\hline 0.15 & 17.6 \\
\hline 0.075 & 6.8 \\
\hline
\end{tabular}

Rothfuch graphical method (Figure 1) is adopted to find the proportion of these materials so that the mix satisfies the gradation requirement. 


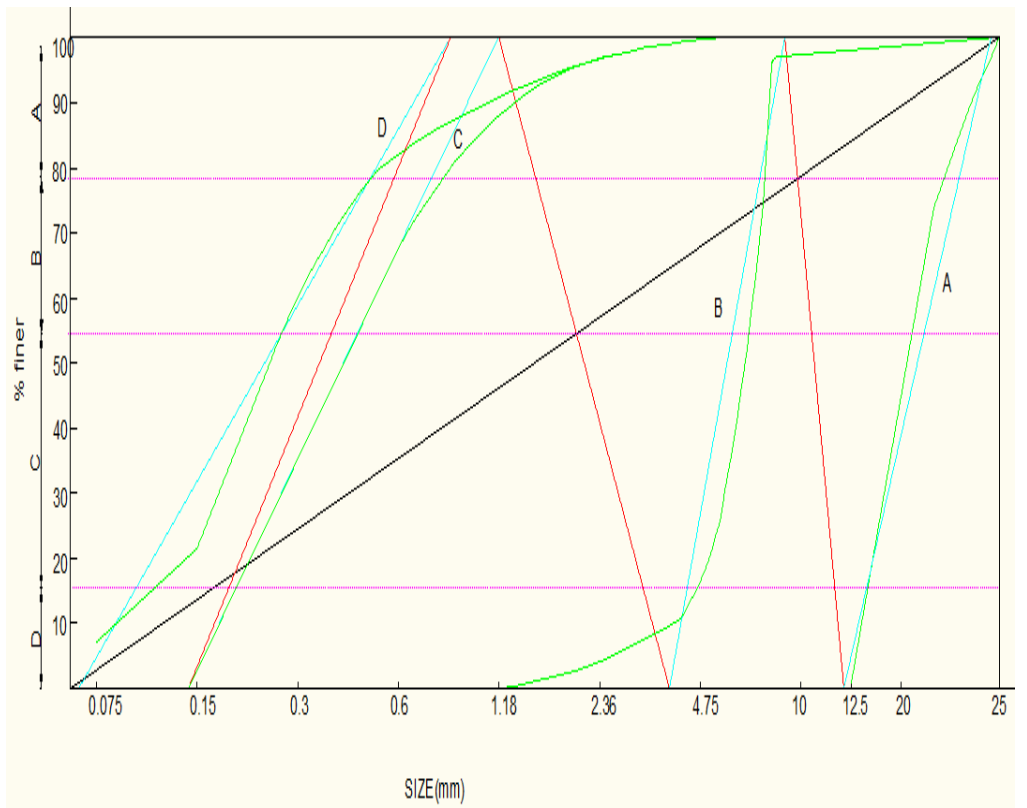

Fig1 Rothfuch graph

From the graph and further analysis, the proportion of the four chosen materials are given: Course aggregate: $16 \%, 10-\mathrm{mm}$ chips: $29 \%$, sand: $28 \%$ and quarry dust: $27 \%$. The percentage finercorresponding to each size for the mix has been given in Table 6.

Table6 Percentage finer vs size for the mix

\begin{tabular}{|c|c|c|c|}
\hline $\begin{array}{c}\text { Sieve } \\
\text { (mm) }\end{array}$ & $\begin{array}{c}\text { \% finer } \\
\text { (Range) }\end{array}$ & $\begin{array}{c}\text { Desired } \\
\text { \% Finer } \\
\text { formix }\end{array}$ & $\begin{array}{c}\text { Achieved } \\
\text { \% Finer } \\
\text { for mix }\end{array}$ \\
\hline 25 & 100 & 100 & 100 \\
\hline 20 & 82 to 100 & 91 & 95 \\
\hline 12.5 & 72 to 93 & 82.5 & 84 \\
\hline 10 & 66 to 85 & 75.5 & 83 \\
\hline 4.75 & 51 to 69 & 60 & 57 \\
\hline 2.36 & 38 to 56 & 47 & 52 \\
\hline 1.18 & 28 to 46 & 37 & 46 \\
\hline 0.6 & 18 to 36 & 27 & 33 \\
\hline 0.3 & 11 to 27 & 19 & 21 \\
\hline 0.15 & 6 to 18 & 12 & 6 \\
\hline 0.075 & 2 to 8 & 5 & 2 \\
\hline
\end{tabular}

For carrying out heavy compaction test as per IS 2720(Part 8) [5], a mix is prepared by adding $0.84 \mathrm{~kg}(14 \%)$ of cement with $6 \mathrm{~kg}$ of solids. The $6 \mathrm{~kg}$ of solids are taken in the proportion already indicated: Mass of course aggregate: $0.96 \mathrm{~kg}(16 \%), 10-\mathrm{mm}$ chips: $1.74 \mathrm{~kg}$ (29\%), sand: $1.68 \mathrm{~kg}(28 \%)$ and quarry dust: $1.62 \mathrm{~kg}(27 \%)$.Now, the mix is subjected to 
heavy compaction test andtheOMC and maximum dry density for the mix obtained are presented in Figure 2.

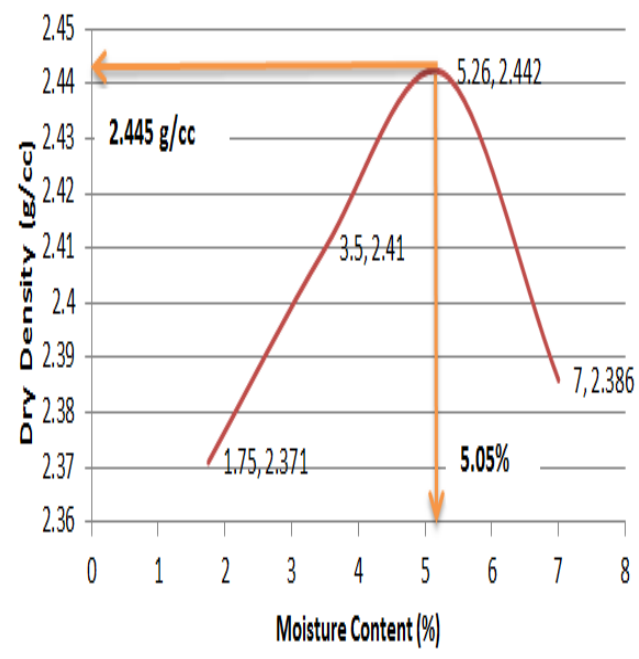

Fig.2 Compaction Curve

From the graphthemaximum dry density $=2.445 \mathrm{~g} / \mathrm{cc}(2445 \mathrm{~kg} / \mathrm{m} 3)$ and Optimum Moisture Content $=5.05 \%$. The designed RCC has seven components, namely course aggregate, 10-mm chips, sand (find aggregate), cement, water and air. For obtaining the masses of various components and their corresponding volumes, the specific gravity of solids is determined and presented in Table 7.

Table 7 Specific gravity of solids of various components of the mix

\begin{tabular}{|l|c|}
\hline Material & Specific gravity \\
\hline Course aggregate & 2.89 \\
\hline 10-mm chips & 2.78 \\
\hline Sand & 2.71 \\
\hline Quarry dust & 2.78 \\
\hline Cement & 3.15 \\
\hline
\end{tabular}

Based on the maximum dry density and the proportion of various components of the mix, the mass of each component is calculated as below:

The total mass of solids + cement per $\mathrm{m} 3$ of the mix $=2445 \mathrm{~kg}$

Mass of solids $=2445 / 1.14=2144.47 \mathrm{~kg}$

Mass of cement $=300.26 \mathrm{~kg}$

Mass of course aggregate $=0.16 \times 2144.74=343.11 \mathrm{~kg}$

Mass of $10-\mathrm{mm}$ chips $=0.29 \times 2144.74=621.89 \mathrm{~kg}$

Mass of sand $=0.28 \times 2144.74=600.44 \mathrm{~kg}$

Mass of quarry dust $=0.27 \times 2144.74=579.0 \mathrm{~kg}$

Mass of water $=.0505 \times 2445=123.47 \mathrm{~kg}$ 
Using the mass of each component and its specific gravity, the volumes are calculated and are presented in a phase diagram (Figure 3). The volume of air is calculated by deducting the total volume of solids (including that of cement) from unity. The percentage of air voids is found to be $0.8 \%$.

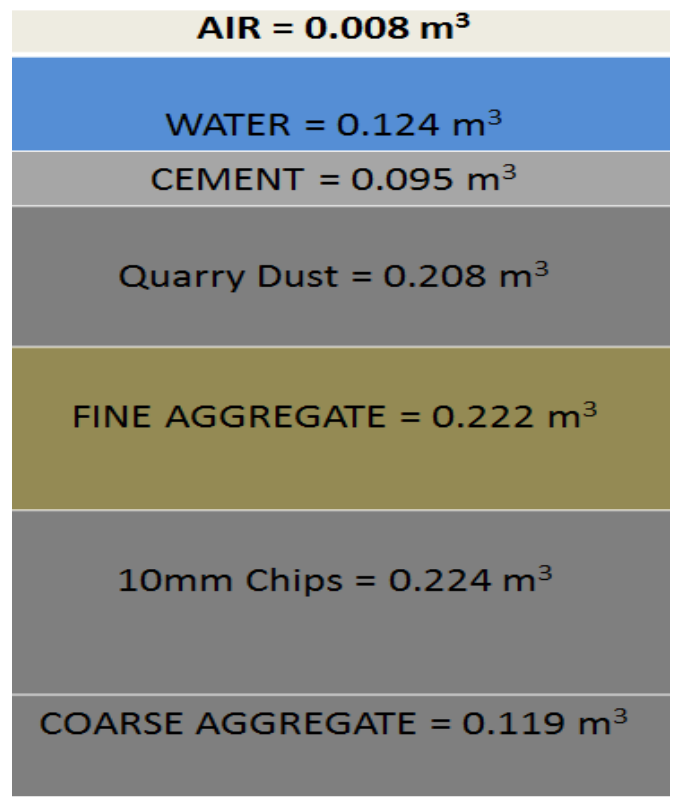

Fig.3 Phase Diagram of RCC

\subsection{Casting of RCC specimens}

Casting of RCC specimens involves a different method of compaction to simulate the field conditions in the laboratory. Compaction is done by compacting using $4.89 \mathrm{~kg}$ rammer producing heavy compaction energy $(2.7 \mathrm{~J} / \mathrm{cc})$ at optimum moisture content. To ensure the compactiveenergyper unit volume to be the same as that given in heavy compaction test, the number of layers and number of blows are calculated as follows,

For square prism (5 layers and 73 blows),

$$
\begin{gathered}
\frac{4.89 \mathrm{~kg} \times 9.81 \times 0.45 \mathrm{~m} \times 73 \times 5}{15 \times 15 \times 13} \\
=2.7 \mathrm{~J} / \mathrm{cc}
\end{gathered}
$$

For rectangular prism (3 layers and 133 blows), 


$$
=2.7 \mathrm{~J} / c c
$$

For cylinder (10 layers and 62 blows),

$$
\begin{gathered}
\frac{4.89 \mathrm{~kg} \times 9.81 \times 0.45 \mathrm{~m} \times 62 \times 10}{\frac{\pi}{4} \times 15 \times 28} \\
=2.7 \mathrm{~J} / \mathrm{cc}
\end{gathered}
$$

The top 2-cm thick loose concrete in all moulds is removed after compacting to avoid the top concrete affecting the quality of the specimen. After 24 hours from the completion of casting, the specimen is demoulded and kept for 28 days curing.

\subsection{Mix proportioning for conventional pavements}

Following the guidelines given by IRC 44:2008 [6], M40 concrete is designed and the proportions of various ingredients are given in Figure 4.

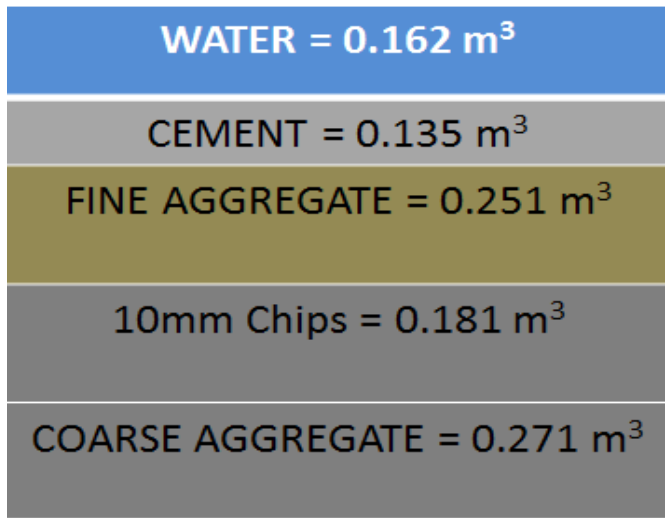

Fig.4 Mix Proportion for conventional concrete

\subsection{Test results}

The test results are given below,

Flexural strength of $\mathrm{RCC}=5.28 \mathrm{MPa}$

Compressive strength of $\mathrm{RCC}=24.57 \mathrm{MPa}$

Flexural strength of Conventional concrete $=5.97 \mathrm{MPa}$

Compressive strength of Conventional concrete $=39.97 \mathrm{MPa}$

There is not much difference in the flexural strength between RCC and the conventional concrete but the compressive strength of RCC is much lower than that of the conventional one. But, in the pavement design, flexural strength rather than the compressive strength influences the requird thickness. 


\section{Design of Pavement}

Using the guidelines given in IRC 58:2011 [7], thethickness of concrete pavement is obtained for the data given in the design example of the code.

Based on the analysis it is found that conventional concrete with a flexural strength of $5.97 \mathrm{MPa}$ requires $250 \mathrm{~mm}$ thick pavement whereas $\mathrm{RCC}$ with a flexural strength of $5.28 \mathrm{MPa}$ requires $280 \mathrm{~mm}$.

\section{Comparison of Cost}

Cost comparison is done ignoring some common aspects between RCC pavements and Conventional Pavements.

\subsection{RCC Pavements}

Cost of construction per unit area of the pavement

Vibratory Roller $=$ Rs $13.8 / \mathrm{sqm}$

Paver finisher $=$ Rs $23.64 / \mathrm{sqm}$

Labour $=$ Rs $2.66 / \mathrm{sqm}$

Materials $=$ Rs $686.72 / \mathrm{sqm}$

Total $=$ Rs $727 /$ sqm

\subsection{Conventional Pavements}

Cost of construction per unit area of the pavement

$$
\begin{array}{ll}
\text { Vibrators } & =\text { Rs } 7.91 / \mathrm{sqm} \\
\text { Labour } & =\text { Rs } 232.85 / \mathrm{sqm} \\
\text { Materials } & =\text { Rs } 837.88 / \mathrm{sqm}
\end{array}
$$

\section{Total $=$ Rs $1079 /$ sqm}

From the above results it is evident that even though roller compacted concrete requires a thicker pavement, it is cheaper compared to the conventional concrete because of the lower cement content required and labour cost. In addition to this, it can be constructed faster.

\section{Conclusion}

Based on the present work, the following conclusions are arrived at

1. Water required for Roller Compacted Concrete (RCC) can be obtained using the concept of laboratory compaction as is done for soils. The term 'water cement ratio is not relevant for RCC.

2. RCC is suitable for paving applications as slump is not a major criterion for pavements 
3. The cement content of RCC is almost half of that of the pavement using conventional concrete and hence it is economical

4. The equipment used in RCC are proving cheaper because of the usage hours being reduced

5. Even though the flexural strength of RCC is $10 \%$ less than conventional concrete, the required pavement thickness doesn't vary much.

6. The cost of RCC pavement is only $68 \%$ of that of pavement made of conventional concrete.

\section{References}

[1]. S.KrishnaRao, "Evaluation of Properties of Roller Compacted Concrete Pavement (RCCP)" International Journal of Education and Applied Research, Vol. 4, Issue Spl-2, Jan - June 2014, pp 88-90

[2]. Mahdi AlikhaniandFereydounmoghadasNejad, "Properties and Performance of Roller Compacted Concrete Pavement and its Economic Evaluation" Indian Journal of Fundamental and Applied Life Sciences, Vol. 5 (S2), 2015, pp 1788-1794

[3]. S. Pavan and S. Krishna Rao, "Effect of Fly Ash on the Strength Characteristics of Roller Compacted Concrete Pavement", IOSR Journal of Mechanical and Civil Engineering, 11(6), Ver. II, 2014, pp 04-08

[4]. V. L. Shruthi, M. Kalpana and D. S. Vijayan, An experimental study on mechanical properties of bitumen added with industrial waste steel stag, Materials Today: Proceedings, https://doi.org/10.1016/j.matpr.2020.03.032

[5]. V. L. Shruthi, M. Kalpana and D. S. Vijayan, An overview of an experimental investigation on mechanical properties of bitumen added with industrial waste - Steel stag, Materials Today: Proceedings, https://doi.org/10.1016/j.matpr.2020.03.261

[6]. ACI 211.3R-02, "Guide for Selecting Proportions for No-Slump Concrete", ACI, 2009

[7]. IS: 2720 (Part 8)-1980, "Methods of test for soils: Determination of water content dry density relation using heavy compaction", Bureau of Indian Standards, 1980

[8]. IRC 44:2008, "Guidelines for cement concrete mix design for pavements", Indian Road Congress, New Delhi, 2008

[9]. IRC 58:2011, "Guidelines for the design of plain jointed rigid pavements for highways', Indian Road Congress, New Delhi, 2011 